\title{
KAJIAN DESAIN KAPAL PUKAT CINCIN YANG BERPANGKALAN DI PUSAT PENDARATAN IKAN ( PPI ) DESA ERI KOTA MADYA AMBON
}

\author{
Obed Metekohy* \\ Program Studi Teknik Perkapalan, Universitas Pattimura, Kota Ambon, Indonesia \\ *E-mail korespondensi: bobmetekohy2710@gmail.com
}

\begin{abstract}
ABSTRAK
The safety of fishermen in fish catch is the main thing that must be consider for a ship designer in designing boats and fishing gear so that fishing operations can be maximized to increase catches and can ensure the safety of vessel, fishing gear and fishermen during fishing operations at sea. This research is aim to examine the design of purse seine vessels based at PPI, Eri village, Ambon City. The method used is a survey method. The results showed that the characteristics of the design parameters of the ship shape coefficient of $30 \%$ and the comparison value of the main size of the ship is $49 \%$ that did not meet the standard value of fishing boat design. So that this ship is not safe to operate the purse seine equipment.
\end{abstract}

Kata Kunci: purse seine, shape coefficient, ship size comparison.

\begin{abstract}
Keselamatan nelayan dalam melaut untuk menangkap ikan adalah hal utama yang harus dipertimbangkan bagi seorang desainer dalam rancang bangun kapal danalat tangkap sehingga operasional penangkapan dapat dimaksimalkan untuk meningkatkan hasil tangkapan dan dapat menjamin keselamatan kapal, alat tangkap dan nelayan selama melakukan operasi penangkapan di laut.Penelitian ini ditujukan untuk meneliti desain kapal pukat cincin yang berpangkalan di PPI desa Eri Kota Madya Ambon.Metode yang digunakan adalah metode survey.Hasil penelitian menunjukkan karakteristik parameter desain koefisien bentuk kapal 30 $\%$ dan nilai perbandingan ukuran utama kapal $49 \%$ belum memenuhi nilai standar rancang bangun kapal ikan. Sehingga kapal ini tidak aman untuk mengoperasikan peralatan tangkap jaring lingkar(purse seine).
\end{abstract}

Keywords: pukat cincin, koefisien bentuk, perbandingan ukuran kapal.

\section{PENDAHULUAN}

Kapal ikan pukat cincin (purse seiner) merupakan tipe kapal ikan yang dalam pengoperasiannya perlu ditinjau secara khusus, karena kapal ini untukinvestasinya menyerap modal yang besar pada usaha penangkapan ikan (Pasaribu, 1986). Pertimbangan aspek teknis dan ekonomis haruslah dipertimbangkan dalam proses perencanaan kapal. Aspek teknis yang harus dipertimbangkan dalam proses perencanaan suatu kapal ikan mencakup konstruksi kapal, kecepatan kapal, stabilitas, daya motor induk, ukuran utama, tata letak ruangan dan material lambung (Fyson, 1985). Selain itu karakteristik daerah penangkapan ikan (fishing ground) yang tidak menentu, haruslah dikaji secara khusus. Karakteristik teknis ini harus menjadi bahan pertimbangan dalam rancang bangun kapal kapal perikanan, sehinggga operasi penangkapan ikan dapat berjalan dengan lancar dan memperoleh hasil tangkapan yang maksimal (Pangalila, 2007) Penyimpangan dari syarat teknis dalam desain dan pembuatan kapal akan menimbulkan dampak negatif bagi keselamatan peroperasian kapal ikan. Laporan dari Komite Nasional 
Keselamatan Transportasi (KNKT) tahun 2007 - 2011 mencatat sebagian besar yaitu $59 \%$ kecelakaan di laut terjadi karena faktor teknis dan $41 \%$ karena faktor manusia (human error) (KNKT, 2011).

Pukat cincin adalah alat tangkap yang digunakan untuk menangkap ikan pelagis yang membentuk gerombolan (Ayodhyoa, 1972). Kapal ikan pukat cincin mempunyai prinsip penangkapan ikan dengan cara melingkari suatu gerombolan ikan dengan jaring, kemudian jaring bagian bawah dikerucutkan dengan menarik talinya untuk memperkecil ruang lingkup gerak ikan, sehingga ikan tidak dapat melarikan dirinya, tertangkap dan terkurung dibagian kantongnya.Kapal pukat cincin mempunyai kemampuan beroperasi di daearh perairan pantai dengan berbagai kondisi cuaca dan iklim, sehingga kapal pukat cincin termasuk dalam kapal perikanan pantai. Perkembangan teknologi kapal pukat cincin semakin maju dalam jangkauan daerah penangkapan yang semakin luas dan jenis ikan pelagis yang tertangkap semakin beragam. Kapal pukat cincin memerlukan adanya tempat penyimpanan jaring, ruang akomodasi, palka ikan, sehingga operasi penangkapan dapat berjalan dengan aman, lancar cepat dan sukses.

\section{a. Alat Tangkap Pukat Cincin}

Definisikan singkatan dan akronim pada kali pertama mereka menggunakan pada artikel, bahkan jika telah didefinisikan di abstrak. Singkatan yang sudah sangat dikenal tidak perlu didefinisikan. Jangan gunakan singkatan pada judul kecuali jika benar-benar tak dapat dihindari. Sub bab diberi nomor huruf.

Alat tangkap pukat cincin didesain untuk mampu menangkap ikan dalam junlah besar yang membentuk kelompok atau gerombolan untuk itu pukat cincin harus dapat :

1). Melingkari secara horizontal, sehingga panjang jaring dan kecepatan melingkarnya harus dipertimbangkan secara baik.

2). Memagari secara vertical dari permukaan sampai kedalaman tertentu, dimana ikan sulit keluar dari lingkaran jaring, sehingga lebar jaring dan kecepatan tenggelam jaring dan tali pemberat harus cukup (Fridman, 2010)

3). Mengurung dengan cepat untuk menutupi bagian bawah jaring, melalui penarikan tali kolor. Untuk itu bagian bawah jaring harus berada lebih dalam dari pada kedalaman menyelam ikan.

Untuk mengoptimalkan operasi penangkapan kapal pukat cincin, maka kapal dilengkapi dengan sejumlah perlengkapan alat tangkap pukat cincin yang terdiri dari jaring kantong (bund), badanjaring (body), jaring sayap (wing), pelampung, tali temali, cincin dan pemberat (singker).

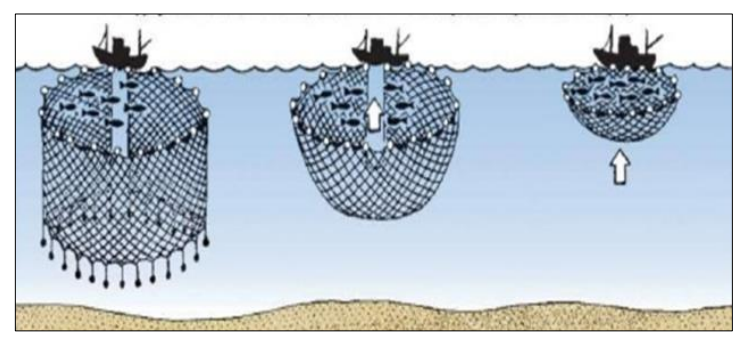

Gambar 1. Pengoperasian Kapal Pukat Cincin

\section{b. Parameter Desain Kapal Pukat Cincin}

Untuk mengevaluasi dan menganalisis parameter desain kapal pukat cincin yang berpangkalan di PPI Eri kota madya ambon didasarkan pada standar nilai karakteristik teknis desain kapal yaitu nilai-nilai perbandingan ukuran utama kapal, dan nilai koefisien bentuk kapal. Nilai karakteristik desain kapal dihitung dengan menggunakan persamaan perhitungan teknik perkapalan (naval arsitecture).

Data kapal dianalisis dengan mengunakan nilai-nilai perbandingan ukuran utama kapal dan nilai koefisien bentuk lambung kapal.

1). Nilai Perbandingan ukuran utama kapal, menurut (Fyson, 1985), meliputi:

- Perbandingan antara panjang dan lebar (L/B), untuk mengetahui kecepatan dan olah 
gerak kapal.

- Perbandingan antara panjang dan dalam (L/D), untuk mengetahui kekuatan memanjang kapal.

- Perbandingan lebar dan dalam kapal (B/D), untuk mengetahui stabilitas dan manover kapal.

Standard nilai untuk analisis karakteristik teknis desain nilai perbandingan untuk kapal pukat cincin di PPI desa Eri Kota Madya Ambon ditetapkan menurut FAO (1996), Fyson (1985), dan Ayodhyoa (1972). Nilai perbandingan kapal adalah sebagai berikut:
$\mathrm{L} / \mathrm{B}=3.10-4.30$
$\mathrm{B} / \mathrm{D}=2.10-5.00$
$\mathrm{L} / \mathrm{D}=9.50-11,00$

2). Koefisien bentuk lambung kapal adalah nilai perbandingan bentuk lengkungan kapal terhadap bidang segi empatskapal. Koefisien tersebut menggambarkan tingkat kelangsingan bentuk lambung kapal. Untuk menganalisis nilai koefisien bentuk lambung kapal (CB, CW, CM, dan CP) digunakan persamaan menurut Nomura dan Yamazaki (1975) sebagai berikut:

- Koefisien Blok: CB $=1.08-\frac{0.5 \mathrm{~V}}{\sqrt{\mathrm{L}^{0.5}}}$

- Koefisien Garis Air: CW $=\mathrm{CB}+0.1$

- Koefisien Gading Tengah: $\mathrm{CM}=0.9+0.1 \mathrm{CB}$

- Koefisien Prismatik: $\mathrm{CP}=\mathrm{CB} / \mathrm{CM}$

Dimana :

$\mathrm{L}=$ Panjang kapal (m)

$\mathrm{B}=$ Lebar kapal $(\mathrm{m})$

$\mathrm{D}=$ Dalam kapal $(\mathrm{m})$

$\mathrm{d}=$ Tinggi sarat air $(\mathrm{m})$

$\mathrm{V}=$ Kecepatan kapal (knot)

Standard nilai untuk analisa karakteristik koefisien bentuk lambung kapal pukat cincin ditetapkan menurut FAO (1996), Fyson (1985), Ayodhyoa (1972), dan Suzuki (1978) yaitu untuk nilai koefisien :

$-\mathrm{CB}=0.40-0.68$

$-\mathrm{CW}=0.76-0.92$

- $\mathrm{CM}=0.91-0.95$

$-\mathrm{CP}=0.55-0.78$

\section{BAHAN DAN METODE (Times New Roman, 11 pt, Bold)}

Penelitian dilakukan di Pulau Ambon pada kapal-kapal pukat cincin yang berpangkalan di PPI Eri. Peralatan dan obyek penelitian ini meliputi alat tulis menulis, meter, tali, komputer (Microsoft office 2010) dan kapal pukat cincin.

Data yang digunakan dalam penelitian ini mencakup data primer dan sekunder. Data primer terdiri dari data hasil pengukuran langsung pada kapal dengan mengukur ukuran pokok kapal.Data sekunder yaitu data penunjang yang dikumpulkan berdasarkan studi pustaka.

Pengukuran kapal untuk mendapatkan ukuran utama dan bentuk lambung kapal dibuat dalam tabel ordinat dengan program Excel Microsoft Office 2010 untuk membuat gambar rencana garis kapal (lines plan), selanjutnya digambar dengan program Auto Cad versi Classic 2010 .

\section{HASIL DAN PEMBAHASAN}

Pukat cincin (purse seine) yang dikenal masyarakat di Maluku dengan jaring bobo adalah kapal yang dalam operasinya menggunakan alat tangkap pukat cincin. Kapal yang menjadi obyek penelitian ini adalah kapal pukatcincin yang berpangkalan di PPI desa Eri Kota Madya Ambon. Kapal pukat cincin ini diklasifikasikan dalam kelompok alat tangkap yang dilingkarkan (encircling gear) karena alat tangkapnya bersifat aktif dan melingkari (Subroto, 2000). 
Tabel 1. Karakteristik Parameter Kapal

\begin{tabular}{ccc}
\hline No & \multicolumn{2}{c}{ Parameter Kapal Penelitian } \\
\hline 1 & LOA (meter) & 14 \\
2 & LBP (meter) & 12.5 \\
3 & LWL (meter) & 12.5 \\
4 & B (meter) & 3 \\
5 & D (meter & 1.5 \\
6 & T (meter) & 1 \\
7 & L/B & 4.16 \\
8 & L/D & 8.33 \\
9 & B/D & 2 \\
10 & CB & 0.56 \\
11 & CW & 0.67 \\
12 & CM & 0.95 \\
13 & CP & 0.6 \\
\hline
\end{tabular}

\section{a. Perbandingan Ukuran Utama Kapal}

Hasil perbandingan ukuran utama kapal memberikan nilai karakteristik teknis desain untuk mengevaluasi apakah kapal pukat cincin yang berpangkalan di PPI desa Eri Latuhalat kota madya Ambon dalam beroperasi di perairan pulau Ambon apakah layak atau tidak layak untuk dapat beroperasi serta dapat menjamin keselamatan kapal dan nelayan selama melaut.

Nilai besaran L/B kapal pukat cincin yang berpangkalan di PPI desa Eri Latuhalat yaitu 4.16 nilainya sesuai besaran nilai yang menjadi acuan. Untuk nilai perbandingan L/D yaitu 8.33 lebih kecil dari besaran nilaiperbandingan yang menjadiacuan. Nilai perbandingan B/D yaitu 2.00 tidak termasuk dalam besaran nilai perbandingan karena lebih kecil dari standar nilai yang menjadi acuan.

Perbandingan L/B digunakan untuk menganalisa kecepatan dan olah gerak kapal (Fyson,1985). Standard perbandingan L/B ditetapkan menurut FAO (1996) dengan nilai standar $\mathrm{L} / \mathrm{B}=3.10-4.30$ mempunyai $\mathrm{L} / \mathrm{B}$ rata rata $=3.8$. Nilai perbandingan $\mathrm{L} / \mathrm{B}$ kapal pukat cincin menurut Suzuki (1978) dan Ayohodya (1972) untuk kapal pukat cincin yang panjang lebih kecil dari 22 meter adalah 4.30 dan nilai L/B untuk kapal pukat cincin yang berpangkalan di Bitung menurut Saiye (1989) adalah 4.32.Dari hasil perhitungan nilai perbandingan $\mathrm{L} / \mathrm{B}=4$.16.Nilai perbandingan L/B kapal ini memenuhi standar nilai dari FAO (1996), tetapi masih dibawah standar kapal pukat cincin di Jepang menurut Suzuki dan kapal pukat cincin yang terdapat di Bitung. Sehingga kapal yang berpangkalan di desa Eri, kecepatan dan manovernya lebih lambat tetapi stabilitasnya lebih baik jika dibandingkan dengan kapal pukat cincin di Jepang dan Bitung.

Perbandingan L/D digunakan untuk menganalisa kekuatan memanjang kapal, (Fyson, 1985 dan Ayodhyoa (1972). Semakin besar nilai perbandingan, maka akan mempengaruhi kekuatan memanjang kapal yang akan menjadi lebih lemah. Standar nilai perbandingan L/D ditetapkan menurut Ayodhyoa dan Suzuki (1978), dengan nilai perbandingan L/D $=9.5-11$, dengan rata rata $\mathrm{L} / \mathrm{D}=10.25$. Dari hasil perhitungan kapal pukat cincin yang berpangkalan di desa Eri kota madiya Ambon, nilai perbandingann L/D $=8.33$. Nilai perbandingan kapal ini lebih kecil 1.17 dari L/D standar, dan nilainya sama besar dengan kapal pukat cincin yang beroperasi di perairan Brondon Lamongan dengan $\mathrm{L} / \mathrm{D}=8.33$, dan nilainya lebih kecil dari kapal pukat cincin yang berada diperairan Bitung yaitu L/D =11,47 (Saiye, 1995).

Kapal pukat cincin dengan nilai perbandingan L/D lebih kecil dari standar memberikan nilai negatif yang melemahkan kekuatan memanjang kapal.Untuk meningkatkan nilai karakteristik teknis desain perbandingan L/D, maka panjang kapal ,harus ditambah sehingga meningkatkan kekuatan kapal menjadi lebih kuat. Kapal pukat cincin di PPI Eri Kota Madya Ambon, kekuatan memanjangnya kapalnya sama dengan kapal pukat cincin yang berada di perairan Brondon Lamongan, tetapi kekuatannya lebih lemah jika dibandingkan dengan kapal pukat cincin yang berada di perairan Bitung. 
Nilai perbandingan lebar dan tinggi geladak kapal (B/D) digunakan untuk menganalisa stabilitas, kemampuan olah gerak dan manover kapal (Ayodhyoa, 1972).

Semakin besar nilai perbandingan B/D maka stabilitas meningkat akan tetapi tahanan kapalnya lebih besar. Standar nilai perbandingan B/D ditetapkan menurut jenis kapal ikan pukat cincin dengan nilai perbandingan untuk panjang kapal lebih kecil dari 22 meter nilai $\mathrm{B} / \mathrm{D}=2.10$ - $5.00(\mathrm{FAO}, 1996)$ dengan ratan $\mathrm{B} / \mathrm{D}=3.0$. Dari hasil perhitungan nilai perbandingan $\mathrm{B} / \mathrm{D}$ untuk kapal pukat cincin yang berpangkalan di PPI desa Eri mempunyai nilai perbandingan B/D $=2.00$, nilai ini lebih kecil dari nilai rata rata $\mathrm{B} / \mathrm{D}$ standar. Apabila dibandingkan dengan nilai B/D kapal-kapal pukat cincin yang berpangkalan diperairan Bitung dengan rasio B/D $=2.62$ (Saiye, 1995) maka kapal pukat cincin di PPI desa Eri masih lebih kecil, menunjukkan tinggi sampai geladak kapalnya lebih besar sehingga turut mempengaruhi stabilitas dan manover kapal. Apabila dibandingkan nilai perbandingannya terlihat kapal pukat cincin di Bitung stabilitasnya lebih baik dan tahannan kapalnya lebih besar dibandingkan kapalpukat cincin yang berpangkalan di PPI desa Eri kota madiya ambon. Untuk meningkatkan nilai perbandingan karakteristik desain B/D yang lebih kecil tersebut adalah dengan menambah lebar kapal sehingga stabilitas dan manovernya semakin baik.

\section{b. Koefisien Bentuk Kapal}

Koefisien kegemukkan kapal (Coefficient of fineness) adalah koefisien yang menggambarkan karakteristik bentuklambung kapal. Parameter-parameter karakteristik teknis desain yang menggambarkan bentuk lambung kapal tersebut adalah koefisien blok (CB), koefisien garis air $(\mathrm{CW})$, koefisien gading tengah $(\mathrm{CM})$ dan koefisien prismatic $(\mathrm{CP})$. Nilai koefisien bentuk lambung kapal cenderung bertambah sejalan dengan bertambahnya tinggi sarat air kapal dengan kisaran $0-1$, apabila nilai koefisien bentuknya semakin mendekati 1 menunjukkan kapal semakin gemuk dan sebaliknya apabila nilai koefisiennya mendekati 0 , menunjukkan bentuk lambung kapalnya semakin ramping, dan jika nilai koefisiennya sama dengan satu maka bentuk lambung kapalnya kotak atau segi empat. Nilai koefisien bentuk lambung kapal dipakai sebagai salah satu cara untuk menilai kelayakkan karakteristik parameter teknis desain kapal.

Koefisien blok (CB) adalah nilai perbandingan antara volume badan kapal yang berada dibawah permukaan air dengan volume balok yang dibentuk oleh panjang (P), lebar (B) dan dalam/tinggi kapal (D). Standar nilai Koefisien blok menurut Ayodhoya (1972) CB $=0.57-$ 0.68, menurut Nomura Yamazaki (1975), untuk kapal ikan CB $=0.4-0.6$ sehingga ditetapkan nilai standar $\mathrm{CB}=0.4-0.68$ dengan nilai rata rata $\mathrm{CB}=0.54$. Koefisien blokkapal pukat cincin yangberpangkalan di PPI desa Eri Kota Madya Ambon, lebih besar $2 \%$ dari CB standar rata rata. Nilai CB antara 0.56 menunjukkan $56 \%$ dari volume kapal adalah dalam bentuk balok. Sehinggga bentuk badan atau lambung kapal ini berbentuk langsing atau sedang. Bentuk lambung kapalnya kurang menguntungkan untuk stabilitas kapal, tetapi dalam beroperasi kapal mempunyai keuntungan karena tahanan air pada lambung kapal yang lebih kecil dan termasuk kapal dengan kecepatan yang normal.Untuk meningkatkan nilai karakteristik desain koefisien bentuk lambung CB yang lebih besar dari standar maka bentuk lambung bagian tengah keburitan harus diperkecil guna mengurangi tahanan kapal sehingga meningkatkan kecepatan kapal dan olah gerak kapal dalammelakukanoperasional penangkapan nelayan dalam melaut.

Koefisien garis air $(\mathrm{CW})$ adalah nilai perbandingan antara luas penampang garis air dengan luas penampang empat persegi panjang yang dibentuk oleh panjang dan lebar empat persegi panjang. Standar CW menurut Ayodhoya (1972) dan Suzuki (1978) adalah 0.76 - 0.92. Dari hasil perhitungan koefisien garis air (CW) kapal pukat cincin yang berpangkalan di PPI desa Eri Kota Madya Ambon, mempunyai nilai $\mathrm{CW}=0.67$, sedangkan standar nilai $\mathrm{CW}$ rata rata $=0.84$. Dari nilai CW rata rata ini, menunjukkan CW kapal penelitian lebih kecil dari CW standar yaitu $0.17 \%$. Nilai $\mathrm{CW}=0.67$ menunjukkan luas bidang yang dibentuk oleh garis air adalah $67 \%$ dari luas bidang garis air dalam bentuk empat persegi panjang. Maka dapat dikatakan luas bidang yang dibentuk oleh garis air pada kapal ini belum mendekati bentuk empat persegi sehingga kurang menguntungkan pada stabilitas kapal, karena memiliki tinggi sarat yang kecil 
dan mempunyai volume cadangan lambung timbul yang besar. Tetapi koefisien garis air yang kecil memberikan nilai positif yang menguntungkan bagi kecepatan kapal karena mempunyai volume terendam kecil sehingga mengurangi tahanan kapal dalam beroperasi (Kantu, 2013). Nilai $\mathrm{CW}$ yang lebih kecil dari standar nilai rata-rata tidak menjamin keamanan dan keselamatan dalam eksplotasi kapal. Sehingga untuk meningkatkan operasional kapal dan menjamin keselamatan kapal dan nelayan selama melaut maka tinggi sarat kapal pada bidang garis air harus diperbesar yaitu dengan menambahkan beban untuk menaikan titik berat kapal sehingga tinggi sarat kapal pada bidang garis air menjadi lebih besar dan dapat meningkatkan stabilitas kapal.

Koefisien penampang gading tengah (CM) adalah perbandingan antara luasan penampang gading tengah yang berada di bawah permukaan air dengan luas penampang segi empat yang dibentuk oleh L,B dan D. Koefisien nilai CM ini, sebagai dasar untuk menganalisa tingkat kegemukkan lambung kapal pada bagian tengah kapal. Standar nilai CM Ayodhoya (1972) untuk kapal ikan jenis pukat cincin adalah 0.91 - 0.95. Hasil perhitungan dari kapal yang berpangkalan di PPI desa Eri Kota Madya Ambon, nilai CM $=0.95$ sedangkan CM standar rata rata adalah 0.93. Nilai $\mathrm{CM}=0.95$ menunjukkan luas penampang tengah kapal adalah $95 \%$ dari luas penampang melintang kapal dalam bentuk empat persegi. Maka dapat dikatakan luas bidang yang dibentuk oleh bidang gading pada tengah kapal mendekati bentuk persegi atau kotak, mempunyai karakteristik bentuk badanatau lambung kapal yang gemuk dengan volume ruang muat yang besar serta mempunyai stabilitas kapal yang baik tetapi memiliki tahanan kapal besar yang menghambat kecepatan kapal. Kapal yang berpangkalan di PPI desa Eri ini, mempunyai nilai $\mathrm{CM}$ lebih besar dari standar rata-rata. Sehingga untuk meningkatkan karakteristik teknis desainnya maka luas bagian tengah kapal ke haluan harus diperkecil untuk mengurangi tahanan air pada bagian haluan dan meningkatkan kecepatan kapal.

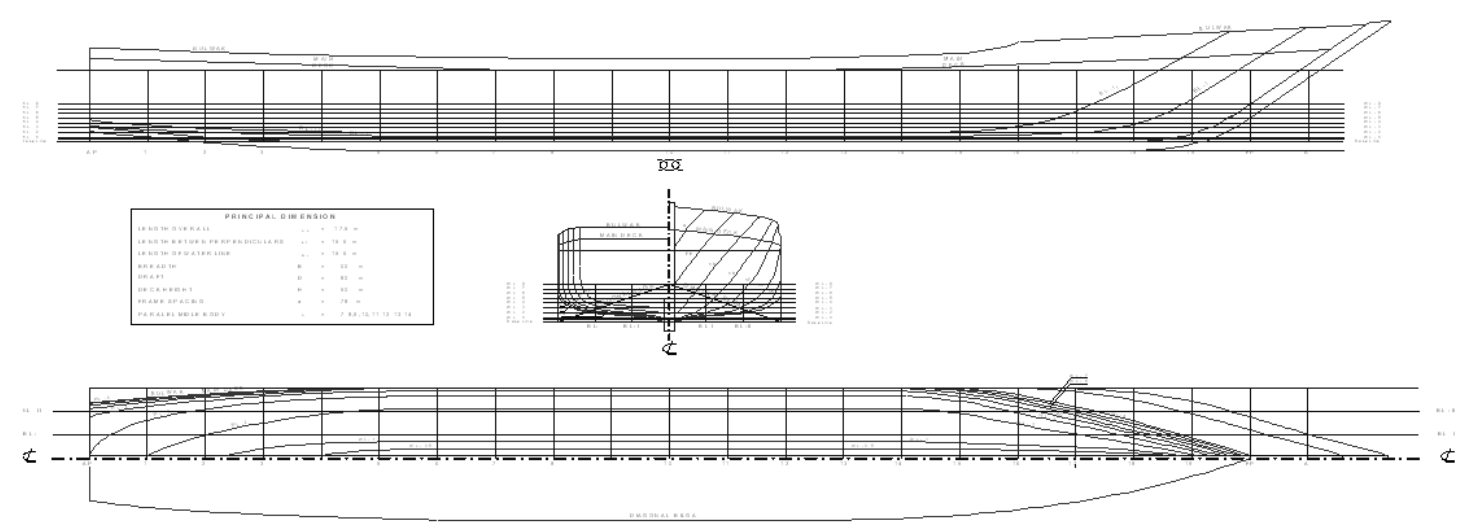

Gambar 2. Rencana Garis Kapal Pukat Cincin di PPI desa Eri Kota Madya Ambon

Koefisien bidang prismatik (CP) adalah perbandingan antara nilai volume displasemen kapal dengan volume yang dibentuk oleh luas penampang melintang tengah kapal dan panjang kapal pada garis air. Standar nilai CP menurut Ayodhoya (1972) untuk kapal pukat cincin adalah $0.55-0.78$. Hasil perhitungan dari kapal yang berpangkalan di PPI desa Eri Kota Madya Ambon, nilai $\mathrm{CP}=0.60$ sedangkan $\mathrm{CP}$ standar rata rata adalah 0.715 . Nilai $\mathrm{CP}=0.60$ menunjukkan volume displasemennya adalah $60 \%$ dari volume kapal yang dibentuk oleh luas penampang melintang tengah kapal dan panjang kapal pada garis air. Nilai CP kapal yang lebih kecil menunjukkan penampang melintang kapal baik ke arah haluan maupun ke arah buritan lebih kecil. Kapal type ini memiliki kecenderungan penampang melintang pada bagian buritan lebih kecil dari penampang melintang tengah kapal, sedangkan pada bagian haluan kapal cenderung berbentuk lancip. Karakteristik kapal dengan nilai koefisien prismatik yang kecil pada bagian buritan sama dengan penampang melintang tengah kapal menunjukkan bentuk kapal yang lancip, memberikan tempat yang sempit diatas geladak dalam operasional 
penangkapan baik pada saat setting maupun hauling dan mempunyai ruang muat yang kecil untuk menampung ikan hasil tangkapan serta mempunyai stabilitas yang kurang baik. Bagian haluan kapal yang cenderung berbentuk lancip menunjukkan karakteristik bentuk haluan yang dapat berfungsi maksimal dalam memecah gelombang untuk mengatasi hambatan atau tahanan sehingga kapal dapat bergerak dengan kecepatan maksimal dalam operasional penangkapan.

\section{KESIMPULAN}

Parameter desain nilai perbandingan ukuran utama kapal L/B, L/D, B/D dan nilai koefisien bentuk kapal yang terdiri dari nilai koefisien blok (CB), Koefisien midship (CM), koefisien prismatic $(\mathrm{CP})$, koefisien waterline $(\mathrm{CW})$ dari kapal pukat cincin yang berpangkalan di PPI desa Eri Kota madya Ambon ini,secara umum tidak sesuai nilai standar rancang bangun perkapalan yang menjadi acuan, dimana rasio ukuran kapal 49\% dan koefisien bentuk $30 \%$ diluar acuan. Sehingga kapal ini tidak aman untuk digunakan dalam mengoperasikan jaring lingkar (pukat cincin).

\section{DAFTAR PUSTAKA}

Ayodhyoa (1972). Fishing Boat Correspondec Cource Center. Fakultas Perikanan, IPB, Bogor Fyson, J. (1985). Design of Small Fishing Vessels.

FAO United Nations. (1996). Fishing New book Ltd. Englands.

Firdman, A. L. (2010). Calculation Fishing Gear Design. FAO United Nations. Fishing New Book Ltd Englands.

Kantu, L. (2013). Desain dan Parameter Hidrostatis Kasko Kapal Fibreglass Type Pukat Cincin 30GT di Galangan CV Bahari Nusantara Minahasa Sulawesi. Jurnal Ilmu \& Teknologi PerikananTangkap, Fakultas Perikanan Dan Ilmu Kelautan Universitas Sam Ratulangi Manado, Volume 1 No 3.

Komisi Nasional Keselamatan Transportasi (2011). Kajian Analisa Trend Kecelakaan Tranportasi. KNKT, Jakarta.

Nomura, M., \& Yamazaki, T. (1977). Fishing Techniques. Japan International, Tokyo.

Pasaribu, B.P. (1986). Pengembangan Kapal Ikan di Indonesia Dalam Rangka Implementasi Wawasan Nusantara. Prosiding. IPB. Bogor.

Pangalila, (2007). Studi Tentang Stabilitas Statis Kapal Ikan Tipe Lambut yang Berpangkalan di Tempat Pelelangan Ikan Aertembaga Kota Bitung Sulawasi Utara. Tesis Program Pascasarjana Unsrat Manado.

Saiye, Z. (1995). Studi Tentang Beberapa Karakteristik Dinamis Kapal Pukat Cincin Di Kecamatan Bitung. Jurnal Fakultas Perikanan Unsrat Manado.

Suzuki, O. (1978). Handbook For Fisheries Scientist and Tecnologist. Training Dept. SEAFDEC Thailand

Subroto, M. A. (2000). Teknik Kapal Penangkap Ikan. Depertemen P\&K, Jakarta 
